\title{
STRATEGI PEMERINTAH DAERAH DALAM MENGATASI ANAK PUTUS SEKOLAH (ATS) DI WILAYAH KABUPATEN KOTAWARINGIN TIMUR
}

\author{
Local Government Strategy in Addressing Dropouts (ATS) \\ in East Kotawaringin District
}

\section{Luci Dian Andayani \\ Muhamad Yusuf \\ Mambang \\ Nicodemus $\mathbf{R}$ Toun}

Universitas

Muhammadiyah

Palangkaraya, Kota

Palangka Raya,

Kalimantan Tengah, Indonesia

*email:

lucidianand@gmail.com

Kata Kunci:

Strategi

Pemerintah Daerah

Anak Putus Sekolah

Keywords:

Strategy

Local Government

Children Drop Out of

School

\begin{abstract}
Abstrak
Penelitian ini bertujuan mengekplore fenomena banyaknya anak putus sekolah dan menganalisa faktor penghambat dari strategi pemerintah daerah dalam mengatasi anak putus sekolah (ATS) di Wilayah Kotawaringin Timur.

Dalam kesempatan penelitian ini dilakukan pendekatan secara analisis kualitatif dengan menggunakan pendekatan deskriptif yang ditunjukan untuk mendeskripsikan fenomenafenomena yang ada. Yang didasarkan pada jangkauan dan kedalaman yang Pengumpulan data dalam penelitian ini didapat dari observasi, wawancara dan dokumentasi. Adapun dokumen terkait penelitian yaitu data penanganan ATS baik berupa petunjuk teknis (juknis), norma standar prosedur dan kriteria (NSPK), pedoman, maupun hasil pendataan dan pelaksanaan kegiatan oleh petugas tenaga lapangan dikmas (TLD) sebagai bahan penelitian.

Hasil penelitian menunjukkan bahwa strategi untuk mengantisipasi dan menangani ATS di wilayah Kabupaten Kotawaringin Timur, pemerintah daerah dengan BAPPEDA sebagai koordinator, mengkoordinir Dinas Pendidikan dalam pelaksanaan kegiatan penanganan anak putus sekolah dengan melakukan koordinasi dan sinergi bersama petugas TLD dalam pelaksanaan pendataan ATS di Kotawaringin Timur. Pendekatan persuasif dari petugas lapangan, membuat anak usia sekolah yang tidak sekolah (ATS) yang berhasil didata bersedia untuk kembali belajar baik melalui jalur formal (sekolah) maupun melalui lembaga-lembaga nonformal seperti Sanggar Kegiatan Belajar (SKB), Pusat Kegiatan Belajar Masyarakt (PKBM), dan Lembaga Kursus dan Pelatihan (LKP).
\end{abstract}

\begin{abstract}
This study aims to explore the phenomenon of the number of children dropping out of school and analyze the inhibitory factors of local government strategies in addressing dropouts (ATS) in The East Kotawaringin Region.

In this research opportunity conducted qualitative analysis approach using descriptive approach shown to describe existing phenomena. That is based on the range and depth that the data collection in this study obtained from observations, interviews and documentation. The documents related to the research are data on handling ATS in the form of technical instructions (juknis), standard norms of procedures and criteria (NSPK), guidelines, as well as the results of data collection and implementation of activities by field personnel dikmas (TLD) as research materials.

The results showed that the strategy to anticipate and handle ATS in east Kotawaringin district, local government with BAPPEDA as coordinator, coordinating the Education Office in the implementation of activities to handle dropouts by coordinating and synergizing with TLD officers in the implementation of ATS data collection in East Kotawaringin. Persuasive approach from field officers, making school-age children who are not school-age (ATS) who are successfully recorded willing to return to study either through formal channels (schools) or through nonformal institutions such as Learning Centers (SKB), Community Learning Activity Centers (PKBM), and Institutes of Courses and Training (LKP).
\end{abstract}




\section{PENDAHULUAN}

Pendidikan memegang peranan yang sangat penting dalam kehidupan dan salah satu faktor yang mendasar unutuk mencerdaskan kehidupan bangsa. Pendidikan juga berperan sebagai sarana pembangunan sehingga sekolah menjadi wadah formal untuk memperoleh pendidikan sebagai salah satu aspek dalam kehidupan manusia yang selama ini diperbincangkan, baik dikalangan praktis maupun teoritis. Undang-Undang Nomor 20 tahun 2003 tentang sistem pendidikan nasional pada Pasal 34 ayat (1-3) menyebutkan bahwa: 1) Setiap warga negara yang berusia 6 tahun dapat mengikuti wajib belajar; 2)Pemerintah dan pemerintah daerah menjamin terselenggaranya wajib belajar minimal pada jenjang pendidikan dasar tanpa memungut biaya; 3) Wajib belajar merupakan tanggung jawab negara yang diselenggarakan oleh lembaga pendidikan, pemerintah dan masyarakat.

$\begin{array}{rrr}\text { Berdasarkan } & \text { ketentuan ini, maka } \\ \text { penyelenggaraan } & \text { pendidikan merupakan }\end{array}$
tanggungjawab bersama baik pemerintah maupun masyarakat dan keberhasilan pendidikan sangat tergantung dari usaha terpadu yang dilaksanakan secara sinergis antara komponen terkait. Mengingat pendidikan merupakan hal yang sangat penting bagi setiap warga negara dan merupakan jalan untuk meningkatkan sumber daya manusia (SDM) sebagai penopang tercapainya pembangunan, baik di bidang ekonomi, sosial, budaya dan bidang-bidang lainya.

Korelasi antara pendidikan dan pembangunan menyangkut bagaimana meningkatkan sumber daya manusia yang berkualitas. Sebab, dengan kualitas sumber daya manusia yang memadai akan mampu menyerap informasi baru yang lebih efektif. Dengan demikian pendidikan merupakan faktor yang sangat penting dalam meningkatkan kualitas hidup suatu masyarakat dalam menjawab tantangan dan perubahan yang dihadapinya. Meskipun berdasarkan pemberitahuan dari United States Trade Representative (USTR) yang dikeluarkan pada 10 Februari 2020, Indonesia sudah dihapus dari daftar negara berkembang, dan saat ini berstatus sebagai negara maju, namun tetap memerlukan usaha yang serius untuk meningkatkan pemerataan pendidikan.

Kebijakan pembangunan di bidang pendidikan diarahkan pada terciptanya pemerataan dan keadilan, program wajib belajar yang telah dicanangkan oleh pemerintah sejak tahun 1994 merupakan tonggak awal dari upaya mencapai pemerataan dan keadilan pada tingkat pendidikan yang semula wajib belajar 6 tahun (usia 7 -12), ditingkatkan menjadi 9 tahun (usia 7 - 15) dan pada tahun 2015 standar ini kembali ditingkatkan menjadi wajib belajar 12 tahun (usia 7 -18) dari jenjang SD sampai SMA. Namun pada kenyataannya hingga saat ini tentu saja tidak dapat dipungkiri bawa masalah putus sekolah masih saja terjadi di seluruh wilayah Indonesia secara umum atau di Kabupaten Kotawaringin Timur sendiri khususnya.

Berdasarkan hasil pendataan Tenaga Lapangan Dikmas (TLD) di Kabupaten Kotawaringin Timur, terdapat hampir seribu anak usia sekolah yang tidak sekolah atau oleh Kementerian Pendidikan disebut sebagai ATS (Anak usia sekolah Tidak Sekolah). Persoalan anak putus sekolah memang bukan sesuatu yang baru untuk menjadi bahan perbincangan, namun persoalan ini begitu urgen untuk dibahas, sebab persoalan ini bersentuhan langsung dengan kemajuan suatu negara, bangsa, dan masyarakat.

Fenomena Anak Putus Sekolah di Kotawaringin Timur ini, dapat terlihat jelas dengan banyaknya anakanak yang berjualan koran, kerupuk, ngamen, dan aktivitas lain yang dilakukan mereka disekitar lampu merah. Padahal kesediaan fasilitas sekolah yang ada di 
wilayah Kabupaten Kotawaringin Timur sudah mempuni dari jenjang PAUD sampai Perguruan Tiggi. Namun Terputus sekolahnya seorang anak atau masyarakat, tentu saja suatu hal yang sebenarnya tidak dikehendaki baik bagi mereka yang mengalami, maupun orang lain yang secara langsung melihat kenyataan ini. Sehubungan dengan itu, Trismansyah (Kulyawan, R. 2014) berpendapat bahwa anak putus sekolah ialah anak yang mengalami kegagalan mengikuti pendidikan di sekolah, sehingga ia berhenti sekolah sebelum waktunya. Anak putus sekolah merupakan anak yang terdaftar di sekolah SD, SMP, SMA namun belum mengelesaikan sekolahnya.

Berdasarkan penjelasan di atas bahwa masalah putus sekolah bisa menimbulkan peristiwa yang melampaui batas dalam masyarakat, sebab orang putus sekolah biasanya menjadi pengangguran yang belum memiliki keahlian untuk bekerja atau menghasilkan untuk memenuhi kebutuhan hidup sehari-hari. Sehingga, peneliti tertarik untuk meneliti tentang "Strategi Pemerintah Daerah dalam mengatasi ATS di wilayah Kabupaten Kotawaringin Timur".

Adapun makna strategi menurut David (Hadijaya, Y. 2013) Strategi adalah pendekatan yang dilakukan oleh lembaga atau organisasi untuk memastikan kinerja yang baik dan berhasil. Sedangkan Menurut Nawawi (Nyoman,2019) Strategi dalam manajemen sebuah organisasi dapat diartikan sebagai kiat, cara dan taktik utama yang dirancang secara sistematik dalam melaksanakan fungsi-fungsi manajemen yang terarah pada tujuan strategi organisasi.

\section{METODOLOGI}

Dalam kesempatan penelitian ini dilakukan pendekatan secara analisis kualitatif, melalui analisis kualitatif mengandung makna suatu penggambaran atas data dengan menggunakan kata dan baris kalimat. Penelitian ini menggunakan pendekatan deskriptif yang ditunjukan untuk mendeskripsikan fenomenafenomena yang ada. Yang didasarkan pada jangkauan dan kedalaman yang diteliti untuk memperoleh pemahaman tentang Anak Putus Sekolah.

Data dan informasi yang digunakan dalam penelitian ini didapat dari observasi dan wawancara. Informasi yang didapat dari observasi langsung, maupun wawancara dan pengumpulan data anak putus sekolah baik dari Tenaga Lapangan Dikmas (TLD) dari Dinas Pendidikan. Informasi tersebut dalam bentuk dokumen dan catatan peristiwa yang kemudian diolah menjadi data.

Adapun dokumen terkait penelitian yaitu data penanganan ATS baik berupa petunjuk teknis (juknis), norma standar prosedur dan kriteria (NSPK), pedoman, maupun hasil pendataan dan pelaksanaan kegiatan oleh petugas tenaga lapangan dikmas (TLD) sebagai bahan penelitian. Kemudian, Peneliti melakukan wawancara kepada pihak terkait seperti Pegawai BAPPEDA Kotawaringin Timur, Pegawai Dinas Pendidikan Kabupaten Kotawaringin Timur, dan Petugas Tenaga Lapangan Dikmas (TLD) untuk mendapatkan data tertentu, terutama apabila data yang diperoleh melalui metode dokumentasi ada yang belum jelas.

\section{HASIL DAN PEMBAHASAN}

Strategi Nasional Penanganan Anak Tidak Sekolah di Indonesia dari Bappenas, bahwa mekanisme pelaksanaan Stranas ATS meliputi tingkat pusat, provinsi, daerah, sampai ke desa. Pemerintah Kabupaten Kotawaringin Timur merupakan bagian dari Tim Teknis Penanganan ATS Daerah yang memiliki peran kunci dalam menginisiasi, mengembangkan dan menerapkan Rencana Aksi Daerah penanganan ATS di kecamatan. Adapun tanggung jawab tim teknis daerah meliputi : 
a) Mengembangkan dan meninjau data ATS, mengidentifikasi kelompok ATS serta faktor penyebab yang dominan berkontribusi pada isu ATS di daerah, baik pada tingkat kecamatan mau pun desa/kelurahan

b) Mengidentifikasi dan merumuskan strategi prioritas dan arah kebijakan untuk penanganan isu ATS di daerah

c) Memetakan layanan pendidikan dan pelatihan, dan kapasitas kelembagaan yang sudah tersediadi daerah, mengidentifikasi kesenjangan, dan potensi pemenuhannya

d) Memantau pelaksanakan program Pemerintah yang sudah berjalan yang berkontribusi langsung untuk penanganan ATS (misalnya berbagai bentuk bantuan sosial dan pendidikan, seperti PIP dan PKH)

e) Mengembangkan Rencana Aksi Daerah untuk mengatasi masalah ATS secara keseluruhan di kecamatan atau desa/kelurahan yang menjadi daerah prioritas (misalnya desa dengan populasi ATS terbesar)

f) Memastikan ketersediaan berbagai sumber daya termasuk dari segi peraturan kebijakan, program, dan penganggaran yang memadai untuk mendukung pelaksanaan seluruh fase implementasi strategi penanganan ATS, termasuk pendataan ATS dan rencana aksi penanganan ATS

g) Menerapkan strategi pendataan ATS yang sesuai, termasuk melakukan pelatihan (SIPBM) di tingkat kecamatan dan desa/kelurahan, melakukan pemutakhiran data terkait ATS secara periodik, dan pengintegrasian data pada tingkat satuan rumah tangga/desa (melalui SIPBM) dengan sistem informasi kesejahteraan sosial yang dikelola pemerintah pusat

h) Meningkatkan kapasitas pemerintah kecamatan dan pemimpin desa/kelurahan untuk melakukan perencanaan pembangunan yang berbasis data akurat, dan mengikut sertakan upaya pendataan dan penanganan ATS di dalam program dan anggaran pembangunan

i) Memantau pelaksanaan Rencana Kerja Pemerintah Desa terkait penanganan ATS dan memberikan dukungan yang sesuai, termasuk pemfasilitasi pembelajaran antar-desa/kelurahan.

j) Mendukung, memfasilitasi, dan mengkoordinasi pelibatan masyarakat dalam seluruh fase perencanaan dan pelaksanaan strategi penanganan ATS di daerah.

Sebelum pencanangan penanganan ATS pada 2017, Pemerintah Kabupaten Kotawaringin Timur sudah mengakomodir warga masyarakat putus sekolah, hanya saja pada saat itu belum ada pembatasan usia sasaran, semua warga masyarakat yang belum menamatkan pendidikan dijalur formal bisa mengikuti pembelajaran di pendidikan kesetaraan.

Setelah pemerintah menetapkan Stranas ATS, Pemerintah Kabupaten Kotawaringin Timur melalui Bidang Pembinaan PAUD dan PNF Dinas Pendidikan melanjutkan penanganan warga masyarakat putus sekolah dengan berfokus pada usia 6-21 tahun.

Gambar 4.1

Salah Satu Anak Putus Sekolah (ATS) yang kembali bersekolah di SNPF SKB Kotawaringin Timur

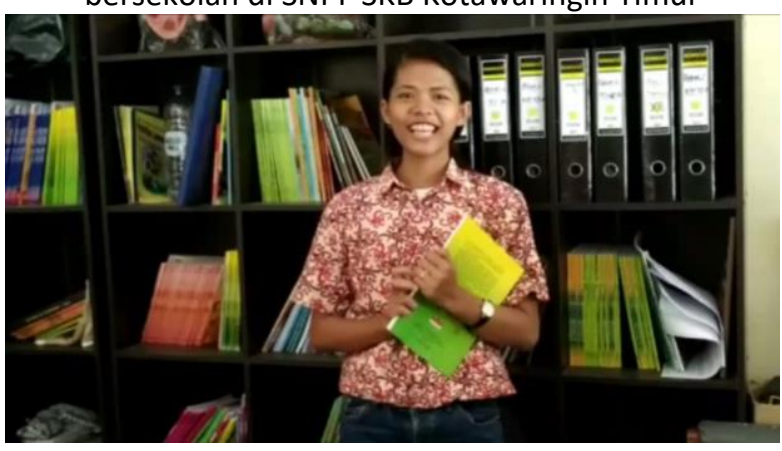

Dinas Pendidikan mengerahkan Tenaga Lapangan Dikmas (TLD) untuk melakukan pendataan di kecamatan sesuais wilayah kerjanya masing-masing. 
Dari hasil pendataan tersebut diperoleh data ATS by name by address yang selanjutnya diberikan pengarahan dan motivasi agar mau kembali bersekolah melalui jalur nonformal.

Pelaksanaan kegiatan ini kurang optimal, karena pendataan ATS yang dilaksanakan di 17 kecamatan, 17 kelurahan dan 168 desa se Kabupaten Kotawaringin Timur dengan jumlah penduduknya mencapai 408.029 jiwa serta luas wilayah 16.796,00 km² dan sebaran penduduk $24 \mathrm{jiwa} / \mathrm{km}^{2}$ ditargetkan selesai dalam waktu 1 bulan saja. Berikut data jumlah ATS pada tahun 2017 sebagai berikut:

Tabel 4.1

Jumlah Anak Usia Sekolah Tidak Sekolah (ATS) Tahun Pelajaran 2017 di Kabupaten Kotawaringin Timur

\begin{tabular}{|l|l|c|}
\hline No & Kecamatan & Jumlah ATS \\
\hline 1 & Bukit Santuai & 21 Orang \\
\hline 2 & Telawang & 40 Orang \\
\hline 3 & Telaga Antang & 10 Orang \\
\hline 4 & Teluk Sampit & 25 Orang \\
\hline 5 & Pulau Hanaut & 26 Orang \\
\hline 6 & Tualan Hulu & 186 Orang \\
\hline 7 & Mentaya Hilir Selatan & 2 Orang \\
\hline 9 & Baamang & 42 Orang \\
\hline 10 & Kota Besi & 81 Orang \\
\hline 11 & Seranau & Jumlah Orang \\
\hline
\end{tabular}

Sumber : Hasil Pendataan ATS oleh Tenaga Lapangan Dikmas (TLD) Kab. Kotawaringin Timur Tahun 2017

Kemudian, melalui catatan media Pro Sampit mengungkapkan data sebanyak 602 anak tidak sekolah. Angka yang diperoleh berdasrkan data tahun 2018. Sehingga perbandingan data 2017 dan 2018 yakni :

Tabel 4.1

Jumlah Anak Usia Sekolah Tidak Sekolah (ATS) 2017-2018

\begin{tabular}{|l|l|c|}
\hline No & Tahun & Jumlah ATS \\
\hline 1 & 2017 & 452 Orang \\
\hline
\end{tabular}

\begin{tabular}{|l|l|c|}
\hline No & Tahun & Jumlah ATS \\
\hline 2 & 2018 & 602 Orang \\
\hline
\end{tabular}

Melalui sajian tabel sederhana ini, menunjukan bahwa dalam rentang waktu 1 tahun dari 2017-2018 ada kenaikan ATS sebanyak 150 orang. Sehingga menunjukan dunia pendidikan di Kabupaten Kotawaringin Timur (Kotim) masih memprihatinkan. Anak-anak di beberapa desa harus putus sekolah dengan berbagai alasan. Selain karena ketidakmampuan ekonomi keluarga untuk menyekolahkan anak mereka, tak ada sekolah juga membuat memupus hak mereka mendapatkan pendidikan.

Sehingga, pemerintah daerah melakukan berbagai strategi dalam menuntaskan permasalahan ATS di wilayah Kabupaten Kotwaringin Timur. Pelaksanaan tersebut, mengacu pada Petunjuk Teknis Bantuan Pendataan Anak Usia Sekolah Yang Tidak Sekolah Tahun 2017 yang diterbitkan oleh Direktorat Jenderal Pendidikan Anak Usia Dini dan Pendidikan Masyarakat, Kementerian Pendidikan dan Kebudayaan Republik Indonesia, indikator keberhasilan program pendataan ATS yaitu:

1. Dana Bantuan Pendataan ATS terlaksana di seluruh kabupaten/kota;

2. Jumlah ATS yang terdata mencapai target anak dengan data lengkap.

3. Tidak ada penyelewengan atau penyalahgunaan dana.

Maka pelaksanaan pendataan ATS di Kabupaten Kotawaringin Timur bisa dibilang berhasil, karena target pendataan untuk Kotawaringin Timur hanya sebanyak 600 anak dan data yang berhasil dihimpun mencapai hampir 1000 anak.

Menurut petugas Tenaga Lapangan Pendidikan Masyarakat (TLD) mengatakan bahwa: 
"Anak putus sekolah di wilayah Kabupaten Kotawaingin timur telah berhasil kami data serta dibujuk/dimotivasi untuk mau kembali bersekolah melalui jalur nonformal di SPNF SKB maupun PKBM terdekat"

Dinas Pendidikan Kabupaten Kotawaringin Timur khususnya Bidang Pembinaan Pendidikan Anak Usia Dini dan Pendidikan Nonformal (Bidang PAUD dan PNF), merupakan koordinator dalam penyelenggaraan program-program pendidikan masyarakat. Kasi Peserta Didik dan Pengembangan Karakter PAUD dan PNF mengatakan bahwa:

"Setelah berakhirnya program pendataan ATS dari Kementerian Pendidikan pada tahun 2017, program penanganan ATS sempat mengalami kevakuman, namun dengan bantuan Petugas Tenaga Lapangan Dikmas (TLD) dan berkoordinasi dengan kepala satuan pendidikan nonformal setempat, akhirnya ATS yang berhasil di data mau dan bisa kembali bersekolah dijalur pendidikan nonformal" Koordinasi yang baik antara Dinas Pendidikan dengan petugas TLD dalam pelaksanaan pendataan merupakan kunci suksesnya pendataan ATS di Kotawaringin Timur. Dengan pendekatan persuasif dari petugas lapangan, anak usia sekolah yang tidak sekolah (ATS) yang berhasil didata juga sudah menyatakan kesediaannya untuk kembali belajar baik di jalur formal (sekolah) ataupun melalui lembaga-lembaga nonformal seperti Sanggar Kegiatan Belajar (SKB), Pusat Kegiatan Belajar Masyarakt (PKBM), dan Lembaga Kursus dan Pelatihan (LKP).

Adapun yang menjadi faktor pendukung dalam pelaksaksanaan program ini yaitu tersedianya petugas pendataan di Kabupaten Kotawaringin Timur yang memang spesifik menangani data dibidang Pendidikan Anak Usia Dini dan Pendidikan Masyarakat yaitu Tenaga Lapangan Dikmas (TLD) yang bertugas di kecamatan, sebagai penghimpun, pengelola, dan supervisor bagi pelaksanaan program PAUD dan Dikmas di wilayah kerjanya.

Selain itu juga tersedia anggaran dari Direktorat Jenderal Pendidikan Anak Usia Dini dan Pendidikan
Masyarakat untuk melaksanakan kegiatan, sehingga untuk keperluan operasional selama pelaksanaan kegiatan bisa terpenuhi.

Dalam pelaksanaan strategi penanganan anak putus sekolah tentu saja ada faktor penghambat yang membuat proses pendataan ATS ini tidak bisa mencapai hasil yang optimal. Faktor penghambat ini antara lain:

1) ketidak pastian jadwal penyaluran dana bantuan pendataan, sedangkan deadline kegiatan semakin dekat;

2) Sulitnya meminta responden untuk jujur mengakui bahwa mereka putus sekolah, hal ini membuat petugas kesulitan untuk menelusuri sasaran pendataan;

3) Tidak adanya pendanaan dari APBD, sehingga kegiatan tidak bisa dilaksanakan secara berkesinambungan, hal ini membuat hasil pendataan yang sudah diperoleh tidak bisa ditindaklanjuti secara maksimal.

Akibatnya adalah, anak tidak sekolah (ATS) yang sudah terdata, hanya sebagian yang bisa disalurkan untuk kembali bersekolah melalui jalur nonformal. Itupun harus disertai dengan koordinasi yang intens dengan satuan pendidikan nonformal seperti SPNF SKB dan PKBM yang ada di wilayah Kabupaten Kotawaringin Timur.

\section{KESIMPULAN}

Strategi untuk mengantisipasi dan menangani ATS di wilayah Kabupaten Kotawaringin Timur, pemerintah daerah dengan BAPPEDA sebagai koordinator, mengkoordinir Dinas Pendidikan dalam pelaksanaan kegiatan penanganan anak putus sekolah dengan melakukan koordinasi dan sinergi bersama petugas TLD dalam pelaksanaan pendataan ATS di Kotawaringin Timur. Pendekatan persuasif dari petugas 
lapangan, membuat anak usia sekolah yang tidak sekolah (ATS) yang berhasil didata bersedia untuk kembali belajar baik melalui jalur formal (sekolah) maupun melalui lembaga-lembaga nonformal seperti Sanggar Kegiatan Belajar (SKB), Pusat Kegiatan Belajar Masyarakt (PKBM), dan Lembaga Kursus dan Pelatihan (LKP).

Sehingga, Sarannya untuk Pemerintah Kabupaten Kotawaringin Timur harus memaksimalkan komunikasi dan koordinasi lintas sektoral dalam penanganan dan pencegahan munculnya ATS baru diluar ATS yang sudah menjadi sasaran pendataan dan penanganan dalam program sebelumnya.

\section{UCAPAN TERIMA KASIH}

Terimakasih yang tak lupa saya ucapkan kepada para Dosen Pembimbing tesis saya yang sudah berkenan meluangkan waktu untuk mengarakan dan membimbing secacra intens tesis saya ini. Serta pada pendampingan tesis yang terus mendorong dan membantu untuk diskusi terkait topik tesis ini. Kemudian juga, para personil FISIPOL UMPR yang sudah membantu saya dalam prsoes administrasinya.

\section{REFERENSI}

Badan Pusat Statistik Kabupaten Kotawaringin Timur, (2020). Kabupaten Kotawaringin Timur Dalam Angka 2020.

Hasbullah. (2010). Otonomi Pendidikan: Kebijakan Otonomi Daerah dan Implikasinya Terhadap Penyelenggaraan Pendidikan. Jakarta: Rajawali Pers.

Hasil Pendataan ATS Kab. Kotawaringin Timur Tahun 2017.

Kementerian PPN/Bappenas (2019). Strategi Nasional Penanganan Anak Tidak Sekolah di Indonesia.

Kulyawan, Roy. Pujiastuti, Widayati. Hanis, Hasdin. (2013). Studi Kasus Tentang Anak Putus Sekolah di Kecamatan Moutoung. Jurnal
Pendidikan Ilmu Pengetahuan Sosial. Fakultas Keguruan dan IImu pendidikan Universitas Tadulako.

Kulyawan, R. (2014). Studi Kasus Tentang Anak Putus Sekolah Di Kecamatan Moutong. Edu Civic, 3(2).

Marzuki, (1994). Meberapa Anak Penyebab Anak Putus Sekolah ( Makalah Utama) Konferensi Pendidikan Nasional III, Medan IKIP Medan.

Muamalah, Bad'ul. (2017). Studi Analisis Penanganan Anak Putus Sekolah di Desa Ngepanrejo Kecamtan Bandongan Kabupaten Magelang. Fakultas Keguruan dan Ilmu pendidikan Universitas Muhammadiyah Surakarta.

Nasution,S. (2010). Sosiologi Pendidikan. Jakarta: Bumi Aksara.

Nyoman Putri Novitasari, N. I. (2019). Manajemen Strategi Program Jalan Lain Menuju Mandiri dan Sejahtera (Jalin Matra) melalui Penanggulangan Kerentanan Kemiskinan (PK2) Di Desa Wringinpitu, Kecamatan Mojowarno, Kabupaten Jombang. Publika, 7(1).

Petunjuk Teknis Bantuan Pendataan Anak Usia Sekolah Yang Tidak Sekolah Tahun 2017.

Sakheraeni, 2012. Masalah Sosial Anak Putus Sekolah (Studi Kasus di Kecamatan Tamalate Kota Makassar). Fakultas Dakwah dan Komunikasi UIN ALauddin Makassar.

Sandhopa, Lennanda. (2019). Analisis Penyebab Anak Putus Sekolah di Desa Bandung Jaya Kecamatan Kabawetan Kabupaten Kepahiang. Fakultas Tarbiyah dan Tadris Institut Agama Islam Negeri (IAIN) Bengkulu.

Suyanto. (2003). Masalah Sosial Anak. Jakarta: Kencana Prenada Media Group.

Syah, Muhibbin. (2010). Psikologi Pendidikan dengan Pendekatan Baru. Bandung: PT Remaja Rosdakarya

Trismansyah, (1998). Anak Putus Sekolah dan Permasalahanya. Jakarta, Percetakan Rosda Karya

Undang-undang Republik Indonesia Nomor 12 Tahun 2008 tentang Pemerintah Daerah. 
Undang-undang Republik Indonesia Nomor 20 Tahun 2003 tentang Sistem Pendidikan Nasional.

Undang-undang Republik Indonesia Nomor 32 Tahun 2004 tentang Pemerintah Daerah.

UU RI NO.3 TH. (1997). Undang-Undang Peradilan Anak. Jakarta: Sinar Grafika 